\title{
Michel Foucault: Poder e Análise das Organizações.
}

Rafael Alcadipani da Silveira. Rio de Janeiro: Editora FGV, 2005. 168 p. ISBN 85.225.0522-5

Resenha por Luiz Alex Silva Saraiva (FUNCESI)

Rafael Alcadipani da Silveira toma para si em Michel Foucault: Poder e Análise das Organizações, uma tarefa complexa: discorrer sobre a obra de Foucault de forma didática e analisar suas possibilidades de leitura e utilização nos estudos organizacionais. Este livro problematiza o uso dos complexos conceitos da obra de Foucault, como a disciplina a biopolítica e a questão da governabilidade, reenquadrando-os à luz das possibilidades de leitura no mundo organizacional. $\mathrm{O}$ livro, assim, dirige-se a leitores de perfil variado, como estudantes de graduação e pós-graduação, professores, pesquisadores e atores do mundo organizacional, interessados na problemática organizacional

Ao longo de cinco capítulos, é construída uma espécie de guia para a leitura das obras de Foucault, uma notável de compilação e reorganização das idéias do pensador francês, de forma a aproximá-lo de um público da área organizacional. Em síntese, o livro apresenta, no primeiro capítulo, uma contextualização das noções foucaultianas usadas na análise organizacional, o que ocorre, no capítulo 2, por uma descrição das principais etapas da obra de Foulcault (genealogia, arqueologia e ética), e pela discussão da analítica do poder. O terceiro capítulo concentra-se nas disciplinas, a face mais conhecida ${ }^{(1)}($ ?) e utilizada das idéias de Foulcault, com enfoque particular na questão do poder sobre os indivíduos. O capítulo 4 trata da biopolítica e da governamentalidade, com desdobramentos interessantíssimos sobre as conexões entre poder, saber e verdade. O último capítulo problematiza a análise organizacional a partir da obra de Foucault, apontando aspectos a serem construídos em torno da obra do pensador francês.

Trata-se de iniciativa incomum no mercado editorial brasileiro, razão pela qual devem receber os parabéns tanto o autor, pela criatividade, quanto a editora, pela coragem de abrir um caminho muito promissor para a confecção de livros provocativos no Brasil. Nesse sentido, é preciso ressaltar a importância desta iniciativa. Muito louvável foi a iniciativa do autor, antes de criticar vigorosamente a produção em torno de Foucault, de discorrer, didaticamente e sem rebuscamentos, sobre os principais aspectos da obra do pensador francês, tornando acessível ao público brasileiro a complexa obra foucaultiana. Merecem destaque 
também o quadro-síntese no final do trabalho, que esquematiza de forma clara o percurso metodológico usado, e as inúmeras possibilidades de pesquisas, a partir do pensamento foulcaultiano descritas no último capítulo.

Contudo alguns posicionamentos sobre a obra de Foucault e sobre os artigos que fizeram uso desta obra desde os anos oitenta são problemáticos, seja pela parcialidade, seja pelo rigor. No que tange ao primeiro aspecto, é claro o envolvimento do autor com o trabalho de Michel Foucault, o que em si não é problema, principalmente se considerarmos que a densidade e a riqueza de suas idéias não são comuns, desde que haja certo senso de que, tal como o próprio Foucault coloca, a verdade não é absoluta. No que se refere ao rigor, em diversos momentos durante o texto, mas principalmente na última parte do livro, as críticas endereçadas aos artigos se baseiam em parte no pressuposto purista de que não se devem misturar as idéias de Foucault com as de nenhum outro autor, o que é improcedente do ponto de vista teórico. Concorda-se que não se pode fazer um uso qualquer das idéias de um autor com base apenas em rápida olhada nas suas páginas, sem maior reflexão a respeito; mas daí a condenar teoricamente as tentativas de estabelecer diálogos com outros autores, é um exagero, um rigor conceitual que parece basicamente enviesado.

Outro problema do livro é a construção metodológica adotada. Embora seja muito interessante recorrer aos artigos publicados nos principais periódicos para mapear as referências à obra de Michel Foucault, mapeamentos deste tipo podem voltar a iniciativa mais "para trás" do que "para frente", o que ocorreu neste livro. Isso significa que o autor, ao identificar nos artigos que os aspectos mais tratados são os relativos ao poder, à biopolítica e às disciplinas, este deveria ser o foco do livro, o que fez com que, por exclusão, elementos pouco explorados da obra de Foulcault, como a noção de governamentalidade apresentada, continuaram desta forma, pois o livro discutiu e analisou apenas o que é mais usado pela academia na área de negócios. Questões foulcaultianas filosóficas e sociológicas mais amplas foram deixadas de lado, devido às opções metodológicas restritivas feitas a partir da ampla estratégia usada, o que deixa a impressão de que, a julgar pelo teor do texto, muito mais poderia ter sido feito em termos de conteúdo, apontando o que a academia na área de Administração não conhece a respeito da obra de Foulcault. Todavia isso não deve ser confundido com o que foi feito: dentro das temáticas abordadas, Rafael Alcadipani da Silveira apontou inúmeros caminhos para a construção de pesquisas baseadas na perspectiva foulcautiana, mas não é a isso que nos referimos; tratamos dos temas não abordados no livro, porque não foram encontrados nos periódicos internacionais.

Toda publicação científica implica coragem em alguma medida, porque, ao expor 
suas idéias, os autores se expõem a críticas, e esta não é uma exceção; mas é importante destacar que os problemas do livro não chegam a fazer sombra à qualidade da obra, que cumpre com competência o objetivo de mapear as idéias mais usadas de Michel Foulcault e discuti-las à luz dos estudos organizacionais, servindo como guia de estudos e como contraponto analítico para muitas iniciativas neste campo, a partir de agora.

\section{Notas}

${ }^{1}$ A julgar pela discussão proposta pelo autor, trata-se de conhecimento superficial, pouco consistente, o que resulta em trabalhos que apenas tangencia os significados atribuídos por Michel Foucault a cada uma das temáticas. 
